\title{
LAB SCALE TEST OF CHARCOAL COMPRESSION STRENGTH: A NEW APPROACH*
}

Martim Hideki Nakayama Kurauchi ${ }^{1}$ Cyro Takano² César Yuji Narita ${ }^{1}$ Marcelo Breda Mourão²

\begin{abstract}
One of the main issues regarding the use of charcoal in metallurgical processes is its mechanical strength, which is much lower than coke. There is no defined standard to determine charcoal compression strength, and the methods described in the literature consist in using a prepared specimen and applying compressing load in the same direction of the charcoal fibres. As charcoal is highly anisotropic, it is proposed a procedure that does not use a specimen and with load applied on a specific direction. Instead, it intends to simulate industrial conditions by randomly dumping charcoal inside a tube, without preferential directional arrangement. This is an attempt to determine charcoal mechanical strength and predict the behaviour of bulk charcoal under a static load, as in a blast furnace. Experiments with controlled loads have been carried out on randomly distributed bulk charcoal with controlled initial size and their effect on the size distribution has been analysed. After compression, charcoal is screened and each size is weighed, determining the particle size distribution of the experiment. This method can therefore be used to evaluate charcoal mechanical strength.
\end{abstract}

Keywords: Charcoal; Mechanical Strength; Compression; Bulk Compression.

1 Metallurgical Engineer, MSc. Candidate, Metallurgical and Materials Engineering Department of the Polytechnic School of the University of São Paulo, São Paulo, SP, Brazil.

2 Associate Professor, Metallurgical and Materials Engineering Department of the Polytechnic School of the University of São Paulo, São Paulo, SP, Brazil.

* Technical contribution to the $44^{\text {th }}$ Ironmaking and Raw Materials Seminar, $15^{\text {rd }}$ Brazilian Symposium on Iron Ore and $2^{\text {nd }}$ Brazilian Symposium on Agglomeration of Iron Ore, September $15^{\text {th }}$ to $18^{\text {th }}$, 2014, Belo Horizonte, MG, Brazil. 


\section{INTRODUCTION}

The iron and steel industry represents around $30 \%$ of the global industrial $\mathrm{CO}_{2}$ emission, with industrial activities accounting for $40 \%$ of the world emissions [1]. Therefore, this sector alone contributes to around $12 \%$ of the total $\mathrm{CO}_{2}$ released to the atmosphere. The majority of the emissions of this industry originates from coal and its derivative, coke, as they are required as reductant and fuel in the blast furnace. Coal is mined from the earth, and its utilisation causes the transfer of carbon from the soil to the atmosphere, contributing to the increase of greenhouse gas emissions.

Charcoal, a renewable alternative, has been used successfully as a substitute for coal and coke as a reductant and is applied in blast furnaces in Brazil [1] and for the production of some non-ferrous alloys, such as FeSi [2]. Opposed to coal, the use of charcoal in metallurgical processes can be $\mathrm{CO}_{2}$ neutral, or even shift the balance towards fixation of carbon to the soil with planted forests [3]. However, there are some significant differences between the use of charcoal and coal/coke for metallurgical processes, such as:

- Lower mechanical strength: makes charcoal transport and handling more difficult, may not withstand loads that could be applied on coal/coke;

- Higher reactivity: charcoal reacts much faster than coal and coke, increasing the reduction reactions speed in the blast furnace, but also generating off-gas with higher $\mathrm{CO}$;

- Lower ash content: less slag is formed when using charcoal than coke, which translates into lower energy consumption as less slag has to be heated and less fluxes have to be added;

- Higher $\mathrm{CaO}$, lower $\mathrm{SiO}_{2}$ : the slag formed by charcoal is naturally basic, requiring less addition of fluxes;

- $\quad$ Lower sulphur, higher phosphorus: decreases the quantity of sulphur that has to be removed from pig iron, requiring less $\mathrm{CaO}$ addition post tapping, but increases the consumption of $\mathrm{CaO}$ in the oxygen refining stage to remove phosphorus.

The lower mechanical strength of charcoal in comparison to coal and coke limits its use in processes such as the blast furnace [4]. This is the reason that charcoal blast furnaces have to be smaller than coke blast furnaces [5].

Charcoal properties are largely influenced by the properties of wood [6]. The natural anisotropy of wood is passed onto charcoal, as part of the wood fibrous structure is preserved. There are few methods to determine charcoal mechanical strength in the literature [7-9] which consist in preparing a test specimen by cutting charcoal into a determined form, eliminating any visible cracks and applying the load in the direction of the fibres. The ASTM standards for coal can generally be applied for charcoal, but there is no standard for compression strength.

During a conventional metallurgical process, there is, so far, no way to position charcoal or coal/coke in an ordered fashion inside a furnace. This decreases the usefulness of testing with a prepared regular sample, as the results of mechanical strength are not accounting for the loads orthogonal to the fibres. The use of randomly distributed charcoal bulks may be a solution to provide better understanding of the anisotropic properties of charcoal, which are not taken into consideration in the experiments with prepared samples. As far as the authors are aware of, there have been no attempts to compress bulk charcoal. There are,

\footnotetext{
* Technical contribution to the $44^{\text {th }}$ Ironmaking and Raw Materials Seminar, $15^{\text {rd }}$ Brazilian Symposium on Iron Ore and $2^{\text {nd }}$ Brazilian Symposium on Agglomeration of Iron Ore, September $15^{\text {th }}$ to $18^{\text {th }}$, 2014, Belo Horizonte, MG, Brazil.
} 
however, previous studies on applying loads in iron ore pellet bulks [10] and straw and hay [11].

This paper proposes a new method to quantify and compare the effects of applying a compressing load on randomly distributed bulk charcoal by observing the size distribution of charcoal after compression. This would allow the comparison between different types of charcoal. Also possible is the quantification of the compression results by means of the size distribution analysis. This could be useful for improvements in charcoal blast furnace design and also for charcoal quality control.

\section{MATERIAL AND METHODS}

The proposed charcoal compression strength test is based on crushing a sample of controlled sized charcoal by applying a determined compressive load and afterwards evaluating the sample size distribution. Figure 1 displays a sketch of the apparatus used to determine charcoal compression strength that has been prepared for these experiments. Load is applied by a compressing test machine (a), which in turn is transmitted to the sample (b) by using an optional transmitting bar (c) that pushes down a round piston $(\mathrm{d})$. A round steel casing $(\mathrm{e})$ retains all the material inside it and is placed on top of a flat surface (f).

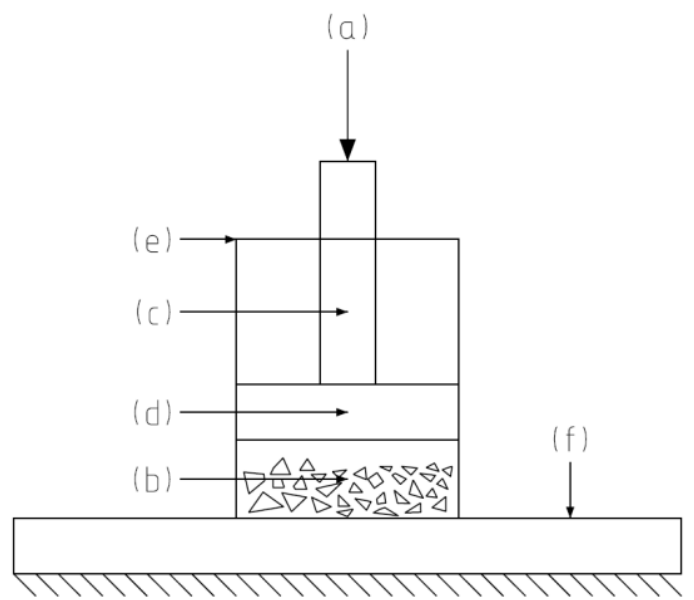

Figure 1. Sketch of the apparatus used for charcoal compression resistance experiments. Load is applied by a compressing test machine (a), which in turn is transmitted to the sample (b) by using an optional transmitting bar (c) that pushes down a round piston (d). A round casing (e) retains all the material inside it and is placed on top of a flat surface $(f)$.

A compressive test machine EMIC model DL 30000, maximum force capacity of $300 \mathrm{kN}$, has been used. A transmitting bar had to be used to avoid damage to the machine and apparatus, as the load cell diameter is almost the same of the casing and there could be high risk of interference between them. The casing is $162 \mathrm{~mm}$ internal diameter. The piston is $56 \mathrm{~mm}$ high and $159 \mathrm{~mm}$ diameter.

Commercially available eucalyptus charcoal for barbecuing has been used in this study. It is crushed into smaller pieces, roughly $3 \mathrm{~cm}$ large, by using hammer and stake. The crushed pieces are screened in sieves with openings of 31.7, 25.4 and $22.2 \mathrm{~mm}$ by using a vibratory machine for 5 minutes. The different sizes are then stored to be used in the experiments.

A $-31.7+25.4 \mathrm{~mm}$ size distribution sample weighing $300 \mathrm{~g}$ is selected and weighed to carry on the compression experiment. This is done to control the charcoal size distribution before and after applying the compressive force and to guarantee reproducibility of the experiment by using the same quantity of material. The sample

* Technical contribution to the 44 Ironmaking and Raw Materials Seminar, $15^{\text {rd }}$ Brazilian Symposium on Iron Ore and $2^{\text {nd }}$ Brazilian Symposium on Agglomeration of Iron Ore, September $15^{\text {th }}$ to $18^{\text {th }}$, 2014, Belo Horizonte, MG, Brazil. 
is randomly dumped into the apparatus shown in Figure 1. It is important to dump the material instead of manually positioning it inside the device. Since charcoal is highly anisotropic, it is expected that a random dump provides unbiased results when a sufficient number of experiments is analysed.

The apparatus is positioned in the compressing test machine, with compressing rate defined as $5 \mathrm{~mm} / \mathrm{min}$ and maximum force set up according to the experiment being held $(5,7,9$ and $14 \mathrm{kN})$. After the compression test takes place, the apparatus and sample are removed from the machine. The sample is weighed and then screened in sieves with openings of $31.7,25.4,22.2,15.9,12.7,9.52$ and $7.93 \mathrm{~mm}$ by using a mechanical shaker. The weight of the different sizes is finally recorded to determine the charcoal size distribution after the experiment. A total of 30 experiments per maximum force value have been carried out.

Charcoal was also analysed according to the proximate analysis practice (ASTM D3172 / ABNT 8112 Standard) to verify if it is representative of a typical charcoal.

\section{RESULTS AND DISCUSSION}

The results of the proximate analysis of charcoal to obtain moisture, volatiles and ash contents are displayed in Table 1. For comparison, "typical" analyses of charcoal from the Industrial Charcoal Making handbook [12] are also shown in Table 1. It is noted that the "typical" values are variable and depend largely of the charcoal making processes. From Table 1 it can be inferred that charcoal used in this study is within the expected values.

Table 1. Proximate analysis of charcoal used in this study and comparison with typical analyses of charcoal obtained from the Industrial charcoal making handbook [12].

\begin{tabular}{lcccc} 
Wood & $\begin{array}{c}\text { Moisture } \\
\text { (wt\%, wet } \\
\text { basis) }\end{array}$ & $\begin{array}{c}\text { Ash } \\
\text { (wt\%, dry basis) }\end{array}$ & $\begin{array}{c}\text { Volatile Matter } \\
\text { (wt\%, dry basis) }\end{array}$ & $\begin{array}{c}\text { Fixed Carbon } \\
\text { (wt\%, dry basis) }\end{array}$ \\
\hline $\begin{array}{l}\text { Eucalyptus sp. } \\
\text { (this study) }\end{array}$ & 3.9 & 1.4 & 23.4 & 75.2 \\
\hline $\begin{array}{l}\text { Eucalyptus } \\
\text { saligna }\end{array}$ & 5.1 & 2.6 & 25.8 & 66.8 \\
\hline $\begin{array}{l}\text { Mixed Tropical } \\
\text { Hardwood }\end{array}$ & 5.4 & 1.2 & 23.6 & 69.8 \\
\hline Oak & 3.5 & 2.1 & 13.3 & 81.1 \\
\hline Coconut shells & 4.0 & 1.5 & 13.5 & 83.0
\end{tabular}

The results of charcoal size distribution after compression are shown in Figure 2 in the form of a box plot. The box plots show the first and the third quartiles of the data in the form of the extremities of the boxes. The median is the line inside the boxes, with maximum and minimum values of the distribution shown as the error bars. Furthermore, the mean of the results is shown as a red slash.

Figure 2 shows that the percentages of particles with larger size (rightmost plots) tend to decrease when the applied force increases. It also shows that the quantity of finer particles (leftmost plots) increases at a faster rate than all other intermediate sizes. This is possibly an indication that upon loading, this particular charcoal tends to break into fine particles rather than into pieces of intermediate size. In that sense, more results with other types of charcoal would be required to verify if this observation is compatible with all charcoals or not.

\footnotetext{
* Technical contribution to the $44^{\text {th }}$ Ironmaking and Raw Materials Seminar, $15^{\text {rd }}$ Brazilian Symposium on Iron Ore and $2^{\text {nd }}$ Brazilian Symposium on Agglomeration of Iron Ore, September $15^{\text {th }}$ to $18^{\text {th }}$, 2014, Belo Horizonte, MG, Brazil.
} 
A similar approach from Figure 2 can be used to analyse the effect of compressing force on the retained particles in each sieve. Figure 3 displays the retained percentages of each sieve correlated with force, also in the format of box plots.

Additionally, Figure 3 contains a plot of the cumulative retained percentages as function of the compressing force. Figure 3 provides better visualisation than Figure 2 with regards to the remark that the quantity of larger sized particles decreases and of finer particles $(-7.93 \mathrm{~mm})$ increases at faster rates than the other intermediate sizes. Therefore, this indicates that when this charcoal was compressed, its pieces did not break homogeneously, but rather broke in different sizes generating higher amount of fines in relation to the other sizes. It does not necessarily mean that all charcoals behave this way upon compression, which has to be verified with other studies.

Also shown in Figure 3, in the cumulative retained plot, is that the average size of the charcoal used in the study decreases with increasing compressing forces, as expected.
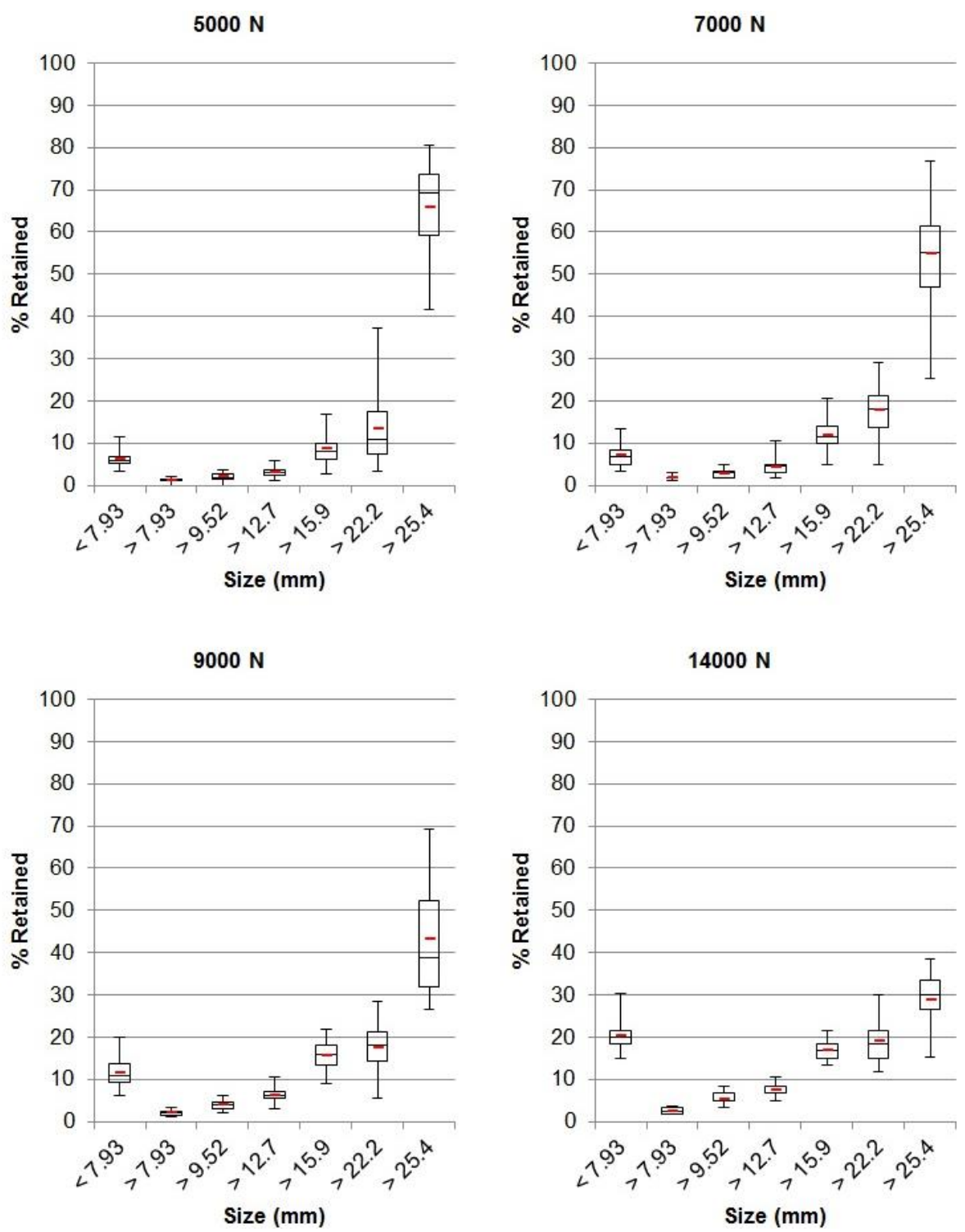

Figure 2. Charcoal size distribution results after compression for $-31.7+25.4 \mathrm{~mm}$ size distributions with varying applied forces ranging from 5000 to $14000 \mathrm{~N}$. The ends of the boxes represent the first and third quartile of the results, from bottom to top, respectively. The lines in the middle of the boxes are the median of the results. The error bars indicate the minimum and maximum of the data. The red slashes indicate the average of the data.

* Technical contribution to the $44^{\text {th }}$ Ironmaking and Raw Materials Seminar, $15^{\text {rd }}$ Brazilian Symposium on Iron Ore and $2^{\text {nd }}$ Brazilian Symposium on Agglomeration of Iron Ore, September $15^{\text {th }}$ to $18^{\text {th }}$, 2014, Belo Horizonte, MG, Brazil. 

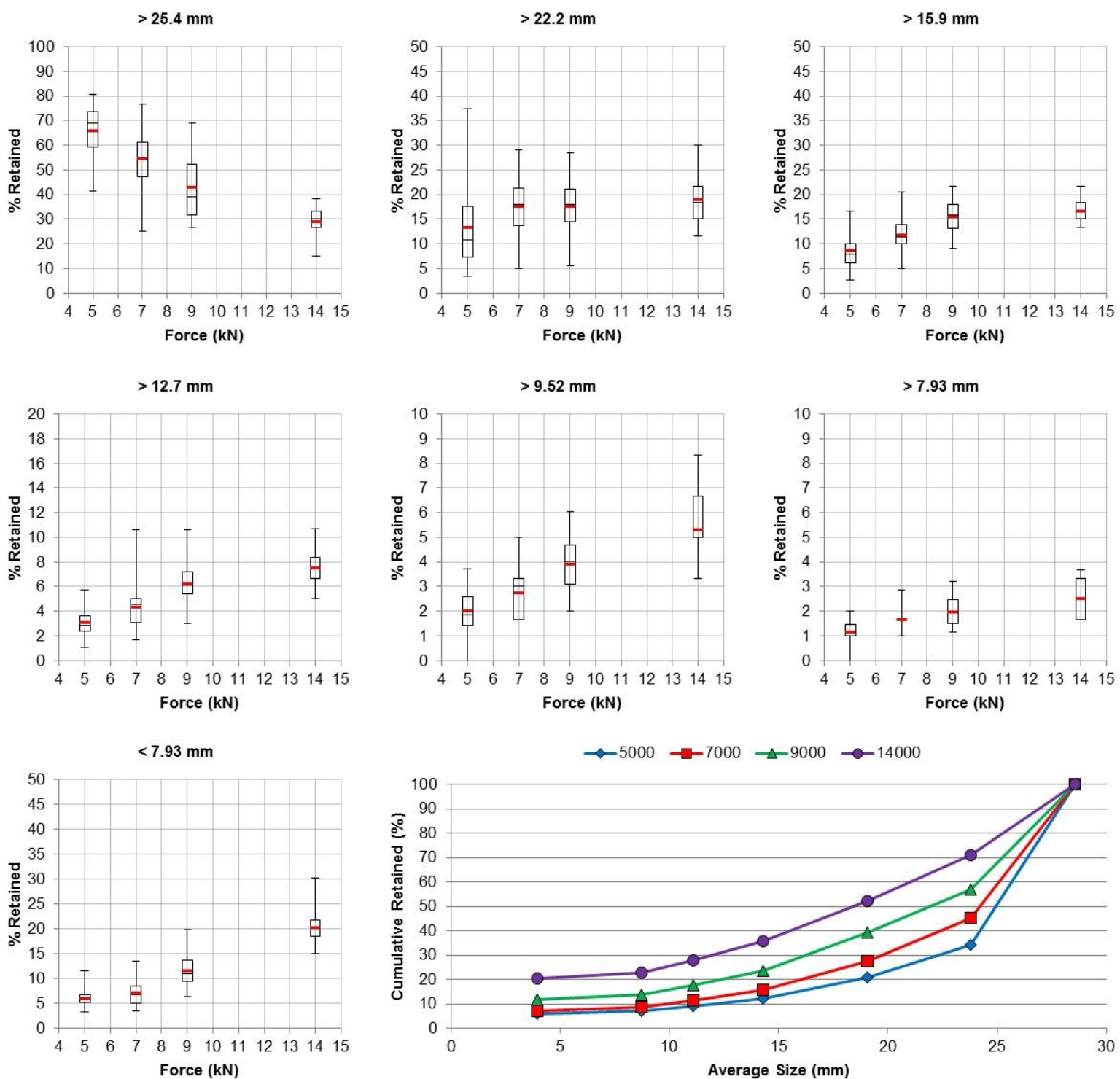

Figure 3. Retained percentages of charcoal on each sieve, correlated with compressing force for samples originally with size distribution of $-31.7+25.4 \mathrm{~mm}$. The ends of the boxes represent the first and third quartile of the results, from bottom to top, respectively. The lines in the middle of the boxes are the median of the results. The error bars indicate the minimum and maximum of the data. The red slashes indicate the average of the data. Where no box is shown $(>7.93 \mathrm{~mm})$, the first and third quartiles are identical. The cumulative retained percentages are also shown in the bottom right corner related with average size.

Figure 3 shows an example of the analysis that can be done to evaluate charcoal quality. By correlating force and retained percentages, it may be possible to compare different types of charcoal by observing:

- The quantity of material retained that has the same size as the original charcoal size (in this case, $-31.7+25,4 \mathrm{~mm}$ ), to compare how resistant charcoal is against crushing;

- The quantity of fine material, to verify if a given charcoal is more or less friable than others upon compressing load;

- The intermediate retained sizes, to assess if different charcoals break in different sizes, either in larger or smaller pieces.

* Technical contribution to the 44 Ironmaking and Raw Materials Seminar, $15^{\text {td }}$ Brazilian Symposium on Iron Ore and $2^{\text {nd }}$ Brazilian Symposium on Agglomeration of Iron Ore, September $15^{\text {th }}$ to $18^{\text {th }}$, 2014, Belo Horizonte, MG, Brazil. 
An example analysis of Figure 3 is done next, by assuming a scenario where charcoal with an original size of $-31.7+25.4 \mathrm{~mm}$ is subjected to a compressing pressure of $100 \mathrm{kPa}$.

As the apparatus of Figure 1 has a compressing area of $\pi \times 0.159^{2}=0.079 \mathrm{~m}^{2}$, $100 \mathrm{kPa}$ is equivalent to $7900 \mathrm{~N} \sim 8 \mathrm{kN}$ in compressing force. From Figure 3 it could then be inferred that around $50 \%$ of this charcoal would still preserve its original size, in average. The quantity of relatively large pieces such as $-25.4+22.2 \mathrm{~mm}$ would be around 18\%; and the quantity of particles finer than $7.93 \mathrm{~mm}$ would be around $8 \%$. The average particle size would be around $22-23 \mathrm{~mm}$.

With an approach similar to the exemplified, it should be also possible to model charcoal behaviour under compression. This could be applicable, for instance, to blast furnace models, or to charcoal piles.

The same principles of this method might be used to other anisotropic materials used in bulk, such as briquettes or extrudes. One example of such applications is the evaluation of the effect of the shape on bulk briquette strength.

\section{CONCLUSION}

The method of compressing bulk charcoal can be used to evaluate charcoal mechanical strength, namely its size distribution after compression. The distribution of the results would allow the comparison of different types of charcoal. Bulk compression can be used to evaluate anisotropic materials, which may not provide sufficient information of the behaviour in bulk, if analysed by using prepared specimens.

\section{Acknowledgments}

The authors would like to thank André Luís Souza, Lucas Teoi and Daniel Song Shimba, undergraduate students of the Polytechnic School of the University of São Paulo, for their collaboration in carrying out the experiments.

\section{REFERENCES}

1 Brown T, Florin N, Fennell P. Reducing $\mathrm{CO}_{2}$ emissions from heavy industry: a review of technologies and considerations for policy makers. Grantham Institute for Climate Change, Imperial College London, London, 2012.

2 Antal MJ, Jr., Gronli M. The Art, Science, and Technology of Charcoal Production. Ind. Eng. Chem. Res., 2003; 42: 1619-1640.

3 Ribeiro TR, Naso PG, Takano C, Mourão MB. Análise do processo de produção de carvão vegetal para siderurgia. In: Redução de Minério de Ferro e Tecnologia Mineral, Vila Velha, 2011: 663-674.

4 International Energy Agency. Energy technology perspectives. International Energy Agency, Paris, 2010.

5 Pfeifer HC, Sousa LG, Silva TT. Design of the charcoal blast furnace - differences to the coke BF. In: 6th International Congress on the Science and Technology in Iron Making, Rio de Janeiro, 2012.

6 Santos RC, Carneiro ACO, Castro AFM, Castro RVO, Bianche JJ, de Souza MM, et al. Correlações entre os parâmetros de qualidade da madeira e do carvão vegetal de clones de eucalipto. Scientia Forestalis,2011; 39,(90): 221-230.

\footnotetext{
* Technical contribution to the 44 Ironmaking and Raw Materials Seminar, $15^{\text {rd }}$ Brazilian Symposium on Iron Ore and $2^{\text {nd }}$ Brazilian Symposium on Agglomeration of Iron Ore, September $15^{\text {th }}$ to $18^{\text {th }}$, 2014, Belo Horizonte, MG, Brazil.
} 
7 Fundação Centro Tecnológico de Minas Gerais. Carvão vegetal: destilação, carvoejamento, propriedades, controle de qualidade. Belo Horizonte, Brazil: CETEC, 1982.

8 Kumar M, Verma BB, Gupta RC. Mechanical properties of acacia and eucalyptus wood chars. Energy Sources, 21, pp. 675-685, 1999.

9 Vieira RS. Propriedades mecânicas da madeira de clones de eucalpytus e do carvão produzido entre $350^{\circ} \mathrm{C}$ e $900^{\circ} \mathrm{C}$. Universidade Federal de Lavras, Lavras, PhD Thesis 2009.

10 Gustafsson G, Häggblad HA, Jonsén P, Marklun P. Determination of bulk properties and fracture data for iron ore pellets using instrumented confined compression experiments. Powder Technology, 241, pp. 19-27, 2013.

11 Nona KD, Lenaerts B, Kayacan E, Saeys W. Bulk compression characteristics of straw and hay. Biosystems Engineering, 118, pp. 194-202, 2014.

12 United Nations. Industrial charcoal making. Rome, Italy: FAO Forestry Paper, 1985.

* Technical contribution to the 44 $4^{\text {th }}$ Ironmaking and Raw Materials Seminar, $15^{\text {rd }}$ Brazilian Symposium on Iron Ore and $2^{\text {nd }}$ Brazilian Symposium on Agglomeration of Iron Ore, September $15^{\text {th }}$ to $18^{\text {th }}$, 2014, Belo Horizonte, MG, Brazil. 